\title{
Investor protection and International Equity Portfolio Investments
}

\author{
Sunil S. Poshakwale ${ }^{\mathrm{a}, *}$ and Chandra Thapa ${ }^{\mathrm{b}}$
}

\section{*Corresponding Author}

$a^{*}$ Centre for Research in Economic and Finance, Cranfield School of Management, England, MK43 0AL, Tel: +44 (0) 1234 754404, Fax: +44 (0) 1234 752554, Email:sunil.poshakwale@cranfield.ac.uk

${ }^{b}$ University of Stirling, Stirling, Scotland, FK9 4LA. Telephone:+ 44 (0) 1786467341 , Fax:+ 44 (0) 1786 467308, Email:chandra.thapa@stir.ac.uk 


\title{
Investor protection and International Equity Portfolio Investments
}

\begin{abstract}
The paper examines the influence of investor protection on international equity portfolio investments. Using bilateral portfolio holdings data for 36 countries for 2001-2006, the study demonstrates that the investor protection measures are important determinants of foreign equity portfolio investments. The findings suggest that by improving the quality and enforcement efficiency of legal protections offered to foreign investors, policymakers may be able to attract greater international equity portfolio investments.
\end{abstract}

JEL classification: G11, G15, F12

Key word: International equity portfolio investments, Investor protection, Developed and developing countries, Fixed effect models 


\section{Investor protection and International Equity Portfolio Investments}

\section{Introduction}

Investor protection has been considered as one of the key factors in explaining the cross sectional differences in the development of capital markets and the ability of corporations to raise external finance. La Porta et al. (1997) hereinafter referred to as LLSV (1997) suggest that markets where contracts are enforced and creditors are protected demonstrate superior operation of debt and equity markets. They argue that since quality of legal rules and their enforcement greatly differ across countries, varying levels of legal protection can explain why firms in some countries raise more funds than in others. Indeed, compared to domestic investors, foreign investors are more vulnerable to the risks of expropriation and hence their decision to invest is significantly influenced by the levels of investor protection. As a direct consequence, foreign investors are willing to invest more in countries where they have greater confidence in the legal institutions. ${ }^{1}$

Foreign investors, often being minority shareholders, are concerned about how well their interests are protected from expropriation by controlling shareholders and managers. La Porta et al., (2000) suggest that expropriation of minority shareholders by controlling shareholders and managers includes direct theft of profit or selling of outputs, assets or securities to other firms at a significantly cheaper price for private benefits of insiders. In other circumstances, expropriation involves diversion of corporate opportunities from the firm by employing unqualified family members in managerial positions, or overpaying executives. Johnson et al. (2000) find that lack of effective corporate governance due to weak legal institutions was partly responsible for the significant losses to foreign investors following the sharp

\footnotetext{
${ }^{1}$ Jensen and Heckling (1976) suggest that where legal rights are extensive and well enforced by regulators or courts, investors are more willing to finance firms.
} 
depreciation of the currency during the Asian crisis in 1997-98. Further, Dialog (1999) demonstrates the vulnerability of foreign investors to expropriation during 1997-98 Asian crises using Korean example where minority shareholders of large firms, that included global companies such as Samsung Electronics, objected to the transfer of cash resources. These transfers were mainly targeted to support other loss making subsidiaries and pay off personal debts.

Previous literature has shown that important features of capital markets can be explained by differences in legal protection available to investors. LLSV (1997) show that better protection of shareholders is associated with higher number of listed stocks, whilst Eleswarapu and Venkataraman (2006) find that better investor protections are associated with larger turnover and liquidity. Others have reported that a strong legal framework for investor protection leads to: higher firm valuation relative to their book value (Claessens et al., 2002), higher dividend payouts (La Porta et al., 2000), widespread control of ownership (La Porta et al., 1999) and reduced managerial private benefits (Zingales, 1994 and Nenova, 1999). It therefore follows that if the quality of investor protection has a positive influence on the development of stocks markets, it should in turn also influence the extent of foreign equity portfolio investments. Thus, the quality and credibility of investor protection measures may help, in part, in explaining why developing countries attract less portfolio investments despite higher economic growth and superior equity returns.

One of the reasons for lower portfolio investments in developing countries is attributed to the existence of several formal and informal barriers which deter foreign investors from investing. Bekaert (1995) suggests that in many developing countries, foreign investors are prevented from owning majority shares and in some countries; higher taxes are levied on profits earned from investment activities. Indirect barriers arise from differences in availability of information, accounting standards, and quality of investor protection and 
enforcement (see Errunza, 2001; Bekaert et al, 2003 and Hunter, 2005). Although Bekaert and Harvey (2000) and Bekaert et al., (2002) have done significant work in demonstrating how different investment barriers affect cost of capital, market volatility and asset pricing, they do not provide direct evidence on how the legal system, quality of legal institutions and foreign investor specific protection measures affect the level of foreign equity portfolio investments.

This paper aims to bridge the gap in the existing literature by providing direct evidence on the relationship between the quality of investor protection regulations and international equity portfolio investments. Using the bilateral equity portfolio holdings data for 36 developed and developing countries and after controlling for a host of confounding variables, we find that investor protection rights, particularly those that directly affect foreign investors, have a positive and statistically significant impact on international equity portfolio investments. Our findings are consistent with those reported earlier that external shareholders prefer to invest in markets that have better investor protection rights to safeguard the interest of foreign investors. The findings provided in the paper offers useful insights to the policy makers particularly in developing countries since it is evident that by improving the quality and enforcement efficiency of legal protections offered to foreign investors, greater levels of foreign equity portfolio investments could be attracted.

The rest of the paper is organized as follows. The following section describes the data used in this study. Section 3 explains the empirical procedure and discusses the results. The final section of the paper provides the main conclusions.

\section{Data}

This study mainly focuses on two sets of data. First comprise bilateral international equity portfolio holdings on county by country basis. The second consists of three different variables capturing various forms of investor protection measures. Both data sets are explained below. 


\subsection{Data on bilateral international equity portfolio holdings}

In October 1997 the IMF undertook a survey, Coordinated Portfolio Investment Survey (CPIS), whereby 29 participating countries began to report their portfolio investment positions on a bilateral basis. The survey is conducted annually since 2001 with an aim to have better understanding of the global asymmetries in the reported balance of payment data, particularly those related to the portfolio investments. All participating countries are required to report a breakdown of their portfolio holdings by the country of residency of the nonresident issuer. The coverage includes the primary end-investors (e.g. banks, security dealers, pension funds, insurance companies, mutual funds, non financial corporations, and households) and primary custodians, who hold or manage securities on behalf of others. ${ }^{2}$ The data are downloadable from the IMF's website. In order to ensure balanced panel for efficient estimation, we have not included data from 1997 since data for all countries included in our sample were not consistently available until 2001. Consequently, we have had to restrict our sample period to 2001-2006. Further since most of the portfolio investments are from developed countries and investments from the developing countries are negligible, we have considered only developed countries as investor countries. A list of investor and recipient countries included in the study are shown in Column 1 of Table 1.

The dependent variable is the logarithmic value of the equity portfolio allocation (weights) from country $i$ into country $j$ and is defined as;

$$
w_{i j t}=\log \left(\frac{F P I_{i j t}}{\sum_{j=1}^{36} F P I_{i j t}}\right)
$$

\footnotetext{
2 However, some caveats deserve due attention. Any investment below USD 500,000 is not reported. Also, some data despite being available may not be reported by a country due to confidentiality reasons. Also, consistent with other studies, we have not included the smaller off-shore financial centres such as Luxembourg and Ireland as target markets.
} 
where $w_{i j t}$ is the weight of foreign holdings from country $i$ into country $j$ for the year $t$ and $F P I_{\mathrm{ijt}}$ is the actual foreign portfolio holdings in USD million.

\subsection{Investor Protection Measures}

Unlike previous studies, two of the three investor protection measures that we use in this study are time varying. These two measures are derived from The Political Risk Services Group's International Country Risk Guide (ICRG). The ICRG provides monthly ratings for political, economic and financial risks for a large number of countries by assigning ratings to each component and sub-component pertaining to each of the three types of risk. The highest number of points indicates lowest potential risk whilst lowest point (0) indicates highest potential risk. The maximum point assigned to a particular component is preset within the system depending on the importance (weighting) of that component to the overall risk for the country. ICRG collects information related to economic, financial and political risks and assesses them for assigning risk points for each individual risk component. The political ratings are solely based on subjective analysis of the collected political information whereas economic and financial risk components' ratings are based on objective assessments.

Two of the three investor protection measures used in this study are from the sub-components of overall political risk ratings as shown in the Table A1 of appendix. The purpose of the political risk rating is to provide a common platform for assessing the political stability of the countries covered by ICRG on a relative basis. The risk rating comprises 12 components rated on the basis of pre-set questions for each component. The annual average of the monthly ratings is used in this study. The third measure is a dummy variable used by La Porta et al., (1998) which shows that English common law system provides better legal protection to shareholders compared to the German and French civil law systems. We use a legal dummy which takes the value of 1 for common law countries and 0 otherwise. Detailed description of each investor protection measure is provided in the following section. 


\subsubsection{Investor Protection I (Investment Profile)}

Out of the 12 sub-components of ICRG's political risk rating, three components are used as measures of investor protection (investment profile) reflecting government's attitude toward inward investment (see Bekaert et al., 2007). The rating of the investment profile is determined by PRS's assessment of three sub-components: (i) contract viability or risk of expropriation (ii) payment delays; and (iii) repatriation of profits. As shown in Panel B of Appendix A1, each subcomponent is scored on a scale with zero indicating high risk and four suggesting very low risk. Increase in this rating indicates improvement in the policies, rules and enforcement of regulations related to foreign investments.

\subsubsection{Investor Protection II (Quality of Institutions)}

Investor protection comprises three sub-components of ICRG's political risk rating components: (i) corruption (ii) law and order and (iii) Bureaucratic Quality (see LLSV, 1998 and Bekaert et al, 2007). ICRG considers that corruption poses a threat to foreign investments because it distorts the economic and financial environment, affects the efficiency of government and business, encourages placement of incumbents on the basis of political connection rather than ability, and finally it creates inherent instability in the political system owing to unhealthy competition for power by corrupt authorities. The most common form of such type of risk related to foreign investments is the financial corruption, such as demand for payments and bribes related to official work, exchange control, tax assessments etc. Such corrupt practices negatively affect the confidence of foreign investors.

ICRG assesses law and order separately. Each component of law and order is assigned maximum of three points. The subcomponent law is an assessment of the strength and impartiality of the legal system. The order subcomponent is an assessment of popular observance of the law. For example, a country may score high (3) rating for quality of law in 
terms of its judicial system but may score very low (0) if the law is ignored without being sanctioned effectively. ICRG (2008) claims that the strength and quality of bureaucracy acts as a shock absorber which tends to minimize the risk of policy instability when government changes. As such, ICRG assigns high points (maximum of 6) to countries where the quality of bureaucracy is strong and efficient enough to govern without drastic changes in the policy or interruptions in government services. In low risk countries, the quality of bureaucracy is somewhat autonomous from high degree of political influence and exhibits well established mechanism of recruitment and training. Countries scoring poorly may lack the cushioning effect because a change in government tends to be traumatic for policy formulation and other administrative functions.

\subsubsection{Investor Protection III (Common English Law)}

Our third variable used as a proxy of investor protection is borrowed from La Porta et al. (1998) who have shown that English common law system provides better legal protection rights to shareholders, while German and French civil law system the least. We use a Legal Dummy which takes the value of 1 for common law countries and 0 for others.

\subsection{Additional Control Variables}

Extant literature has shown that investors do not allocate investments according to the theoretical assumptions of ICAPM and tend to significantly overweight their home markets causing the actual portfolio weights to deviate from the global market portfolio as assumed in the ICAPM (see French and Poterba 1991; Tesar and Werner, 1995; Warnock, 2001 Karlsson and Norden, 2007 among others). Following Fidora et al., (2007) we construct the following bilateral home bias $\left(\right.$ Hbias $\left._{i j t}\right)$ measure that would control for the home bias:

$$
\text { Hbias }_{i j t}=1-\log \left(w_{i j t} / B W T_{i j t}\right)
$$


where Hbias $_{i j t}$ is bilateral home bias for investor country $i$ for country $j$ at time $t . B W T_{i j t}$ is defined as the benchmark weight and is computed as

$$
B W T_{i j t}=M C_{j t} /\left(\sum_{j=i}^{36} M C_{j t}\right)
$$

where $M C_{j t}$ is the market capitalization of the issuer country $j$ at time $t$.

Although the use of home bias proxy as a control variable as warranted by the existing literature, the measure, by construction, includes the bilateral international equity portfolio allocation and may therefore affect the regression results. We address this by adding an interactive term of home bias and each of the investor protection measure ${ }^{3}$.

In addition to the home bias measure and the interactive term, we include several other control variables that may influence foreign portfolio investments. First, equity market development/size has been shown to affect the investment decisions of foreign investors. Chan et al. (2005) suggest that foreign investors tend to allocate more funds in markets which are bigger and relatively more developed. We include logarithmic ratio of stock market capitalization to GDP as a measure of stock market development and size. We obtain this measure from World Bank Indicator (WDI). Second, we use the turnover ratio as a proxy for measuring trading liquidity and transaction costs (see Gelos and Wei, 2005). Third, we use yearly cross sectional standard deviation of the monthly equity returns for each country to capture potential uncertainty of future returns. It has been shown that foreign investors avoid investing in markets that exhibit high historical volatility and thus we expect that coefficient for this variable should carry a negative sign. Fourth, foreign portfolio investments are

\footnotetext{
${ }^{3}$ We the referee for correcting the specification issue.
} 
influenced by long term bilateral relationship, geographic proximity and market familiarity. We use a common language dummy which takes the value of one if the pair country shares a common language. We also include the logarithmic distance (in kilometers) between the capital cities of the pair countries to capture geographic proximity. Both variables are obtained from www.nber.org/ wei/data.html and have been previously used by Subramanian and Wei (2006). Further, bilateral trade agreements have been shown to play an important role in attracting cross border foreign investments (Chan et al., 2005). Thus, we use bilateral trade variable by calculating the total export and import for each pair country. The data is obtained from Bilateral Trade Statistics of IMF. Fifth, the tendency of foreign investors to invest in countries with higher historical returns is commonly referred to as 'return chasing' or 'feedback' hypothesis (see Bohn and Tesar, 1996 for US markets Griffin et al, 2004 for emerging markets). We calculate three year moving average of historical returns (based on monthly total return index of MSCI) and include this in our model to capture the possible effects of the return chasing hypothesis. We expect the regression coefficient on this variable to bear a positive sign.

We also include two broad country risk measures obtained from the Political Risk Group. First is 'financial risk' that is based on a scale of 0-50 for five financial components (foreign debt as \% of GDP, exchange rate stability, foreign debt as \% of total export and services, current account as \% of exports and services and international liquidity). The second is 'economic risk' that is also measured on a scale of 0-50 points and which includes five components (GDP per head, Real GDP growth, inflation rate, budget balance as \% of GDP, current account as \% of GDP). Finally, we also include a capital control measure index constructed by Chin and Ito (2008). The index is publicly available and can be downloaded from http://www.ssc.wisc.edu/ mchinn/research.html. The index is based on four major restrictions on external accounts namely, presence of multiple exchange rates, restrictions on 
current account transactions, restriction on capital account transactions and requirements regarding surrender of export proceeds. The index has a mean value of zero and takes higher values for more open economies. For example, for 2006 in our sample, China, India and Turkey have strong capital controls and thus the index measure is -1.13 while open economies such as the UK and the USA carry an index value of 2.54 .

\section{Empirical Findings}

We present the empirical finding of our analysis based on both simple descriptive statistics and more rigorous panel data regressions. We first discuss the result of descriptive statistics followed by the findings of regression analysis.

\subsection{Descriptive and Rank Statistics}

Column 2 of Table 1 shows average foreign portfolio allocation received by different countries over the period of six years (2001-2006). The third and fourth columns show average rating of each country in terms of Investor Protection Indicators, IPI and IPII. The fifth column shows the composite rating based on scores for IPI and IPII and the final column reports the dummy for the legal system followed by countries. Overall, countries have been ranked on the basis of composite investor protection index (IPI+IPII).

All of the top fifteen countries in terms of investor protection ratings are developed countries which also receive almost $86 \%$ of the total foreign equity portfolio investments. The bottom fifteen countries are all developing countries with the possible exception of Greece and these countries receive approximately $5 \%$ of the total international portfolio allocation. Notably, countries that use the Common English Law receive around 58\% of the total international portfolio investments. We also conduct the statistical test of spearman rank correlation to confirm the potential relationship. The rho value of the Spearman tests between international equity portfolio allocation and the three measures of investor protection, i.e. IPI, IPII and IPII 
are $0.47,0.27$ and 0.19 respectively. In all three cases, we reject the null of no independence at statistical significance level of $5 \%$ and $1 \%$. The findings show that countries receiving higher international portfolio allocation also rank high on the composite investor protection index providing an early indication of a positive relationship between better investor protection and higher international portfolio investments.

\section{Insert Table 1 here}

\subsection{Regression Results}

We use data for 36 countries (destination countries) with bilateral equity portfolio allocation from investors of 16 developed counties (investor countries) for a period of six years. We utilize a panel data framework and employ fixed effect model to mitigate any potential endogeneity arising from unit specific effect. Thus where we use IPI and IPII which are time varying measures, we estimate the regressions using fixed effect model ${ }^{5}$. However, the third investor protection measure (IPIII) is a time invariant variable and hence we use the random effect model. The test-statistics are based on robust standard errors given the possibility of country specific clustering in our data.

Since our empirical approach is aimed at examining whether investor protection measures have any significant impact on international equity portfolio allocations, we run the following base model that controls for the home bias with an interactive term:

$$
w_{i j t}=\alpha+\beta_{1} \text {. Hbias } \text { ijt }_{1}+\beta_{2} \text {. Hbias_IP } P_{i j t}+\beta_{3} . \text { Investor protection }_{j t}+\epsilon_{i j t}
$$

\footnotetext{
${ }^{4}$ We thank the anonymous referee for suggesting the statistical test.

5 Our fixed effect estimation could be inefficient due to serial correlation in the error. We use Prais-Winsten regression with country dummies that allows for country specific effects for addressing heteroskedasticity using robust standard error. Our results are similar to the ones reported but do not report these for saving space. However, 
The coefficient for investor protection variable is expected to be positive since international investors prefer countries with better investor protection rights. The regression results are presented in Table 2. As expected, the coefficients for investor protection measures are positive and statistically significant at $5 \%$ level. The coefficients for home bias are negative and highly significant confirming the widely reported phenomenon of home bias in international portfolio allocation decisions. The results suggest that after controlling for home bias, different levels of investor protection measures do significantly influence foreign equity portfolio investments. The statistical significance and the negative sign of interactive term suggest that improvement in investor protection framework becomes less effective in attracting foreign equity portfolio investment if investors' exhibit extensive home bias for the respective country. However, results presented in Table 2 may not be entirely reliable since foreign portfolio allocations may be influenced by a variety of other factors discussed in section 2.3. In the following sections, we run regressions using different specifications which incorporate various control variables.

Insert Table 2 here.

\subsubsection{Omitted variables bias}

The first issue we deal with relates to the omitted variable bias. Our regression coefficients estimated in specification (1) may be biased in the absence of the various control variables. Thus in regression specification (2), we include control variables, including home bias and the interactive term, while accounting for individual country and time effects by including country and time dummies.

$$
w_{i j t}=\alpha+\beta_{1} . \text { Investor protection }_{j t}+\beta_{2} . \text { Controls }+\epsilon_{i j t}
$$

The results reported in Table 3 show that size of the coefficients for Hbias and investor protection measures is lower than those estimated via specification 1 . The inclusion of the 
control variables and country and time dummies seem to account for the possible omitted variable bias in specification 1. However, coefficients for investor protection measures remain positive and statistically significant.

.Insert Table 3 here............

\subsubsection{Reverse Causality}

Endogeneity arising from reverse causality could be another potential problem in our estimations since growth in international equity portfolio investment may in turn improve the regulatory environment of the recipient country (see Errunza, 2001). We address this issue by using one year lagged value of investor protection measure ${ }^{6}$ and estimate specification (3).

$$
w_{i j t}=\alpha+\beta_{1} \text {. Investor protection } \text { it }-1+\beta_{2} \text {. Controls }+\epsilon_{i j t}
$$

Results reported in Table 4 suggest that while the coefficient for IPI is positive and statistically significant, coefficient for IPII is not significant anymore. This may suggest that foreign investors may be more concerned with investor protection measures that directly affect their investment interests which are proxied by IPI. The findings are consistent with Bekaert et al. (2007), who also find that foreign investors are more concerned about those aspects of legal and regulatory environment, which directly affect them rather than overall quality of institutions captured by IPII in our analysis.

.Insert Table 4 here.............

\footnotetext{
${ }^{6}$ The use of lagged values of the indices also addresses the possibility of the investors acting on the basis of expected investor protection measures. We do not include the IPIII in specification 3 because it is a time invariant dummy variable
} 
Furthermore, following Gelos and Wei (2005) we run the vector autoregression between the international portfolio allocation and investor protection measures using following specification:

$$
\begin{aligned}
& w_{i j t}=\alpha+\beta_{1} \cdot w_{i j t-1}+\beta_{2} \text {. Investor protection } \text { prt-1 }_{j}+\beta_{3} \cdot \text { Controls }+\epsilon_{i j t} \\
& \text { Investor protection }_{j t}=\alpha+\beta_{1} \text {. Investor protection } \text { Int-1 }_{j}+\beta_{2} \cdot w_{i j t-1}+\beta_{3} . \text { Controls }+\epsilon_{i j t}
\end{aligned}
$$

As reported in Table 5, IPI granger causes foreign equity portfolio allocation but IPII does not. Similarly, international equity portfolio allocations do not granger cause both, the IPI and IPII. The vector autorgression results confirm the significance of IPI ${ }^{7}$.

\subsubsection{Major Financial Centers}

Next, we consider the possibility that international investors may choose to buy foreign stocks in major financial centers instead of directly investing in foreign equity markets. International investors may be tempted to use major financial centers, such as USA, UK and Japan, to directly buy the cross-listed stocks and/or depository receipts because they may perceive that their investor protection rights are better protected by regulations in major financial centers (Reese and Weisbach, 2002). In order to accommodate this possibility, we exclude USA, UK and Japan from our sample and run the following specification:

$$
w_{i j t}=\alpha+\beta_{1} \cdot \text { Investor protection }_{j t}+\beta_{2} . \text { Controls }+\epsilon_{i j t}
$$

\footnotetext{
${ }^{7}$ The between effect estimations, which discard the time series information, also yield similar results with IPI and IPII being statistically significant and not IPII.
} 
Results reported in Table 6 show that despite excluding major financial centers, all three investor protection measures remain positive and statistically significant thus confirming that investor protection remains an overwhelmingly top consideration for foreign investors.

\section{Insert Table 6 here.}

\subsubsection{Other control variables}

Estimated coefficients for most of the control variables carry the expected sign and statistical significance except for the coefficients of historical returns and capital controls, which are either not significant or change sign in different regression specifications. However, consistent with previous studies, we too find that among other control variables, equity market development is one of the most significant factors followed by liquidity/transaction cost, equity market volatility and bilateral familiarity variables (see Gelos and Wei, 2005 and Chan et al., 2005). The findings seem to suggest that that investors prefer to invest in markets, which have adequate depth; breadth and exhibit lower market volatility. The statistical significance of investor protection measures, particularly IPI and IPII, appear to feature consistently in most regression specifications. This implies that by strengthening the protections frameworks offered to foreign investors, greater foreign portfolio investments could be attracted.

\section{Conclusions}

Factors influencing international portfolio allocation decisions have significant theoretical and practical relevance for academic research and policy makers. This paper examines the influence of investor protection on the behavior of bilateral international equity portfolio investments. By using two different stands of the literature, one that deals with investor protection and capital market development and the other that is concerned with the impact of investment barriers on foreign portfolio investments, this study provides evidence that 
international investors prefer to invest in markets that have better investor protection measures in place. The findings suggest that measures specific to protecting the rights of foreign investors seem to matter most. Also, countries which use common English law appear to attract higher level international equity portfolio investments. Further, though investor protection reflected via the quality of institutions (IPII) is found statistically significant in most specifications; it does not seem to rank as highly and consistently as the regulations which directly protect the rights of foreign investors.

The findings suggest that the quality and enforcement efficiency of legal protections accorded to foreign investors should be an important policy matter for attracting higher level of foreign equity portfolio investments. Our findings confirm that investor protection measures, particularly specific to foreign investments, are an important cross sectional determinant of international equity portfolio investments. The evidence provided in this paper extends and enriches the previous literature and confirms that foreign investors prefer investing in markets that have stronger foreign investor protection rights. 


\section{AppendixA1: Decomposition of ICRG's Political Risk Components}

Panel A: Overall Political Risk Components

\begin{tabular}{llc}
\hline Sequence & Component & Points (Max) \\
\hline & Government Stability & 12 \\
A & Socioeconomic Condition & 12 \\
B & Investment Profile & 12 \\
C & Internal Conflict & 12 \\
D & External Conflict & 12 \\
E & Corruption & 6 \\
F & Military in Politics & 6 \\
G & Religious Tension & 6 \\
H & Law and Order & 6 \\
I & Ethnic Tensions & 6 \\
J & Democratic Accountability & 6 \\
K & Bureaucracy Quality & 4 \\
L & & $\mathbf{1 0 0}$ \\
TOTAL & & \\
\hline
\end{tabular}

Panel B: Investment Profile: Investor Protection Measures Specific to Foreign Investment

\begin{tabular}{llc}
\hline Sequence & Sub-Component & Points (Max) \\
\hline & & \\
C & Contract Viability/Expropriation & 4 \\
C & Profit Repatriation & 4 \\
C & Payment Delays & 4 \\
TOTAL & & $\mathbf{1 2}$ \\
\hline
\end{tabular}

Panel C: General Investor Protection Measure

\begin{tabular}{llc}
\hline Sequence & Components & Points (Max) \\
\hline & & 6 \\
F & Corruption & 6 \\
I & Law and Order & 4 \\
L & Bureaucracy Quality & $\mathbf{1 6}$ \\
TOTAL & & $\mathbf{1 6}$ \\
\hline
\end{tabular}




\section{References}

Atje, R. and B. Jovanovic, 1993, Stock Markets and Development, European Economic Review 37, 632-640.

Bekaert, G, 1995, Market Integration and Investment Barriers in Emerging Equity Markets, The World Bank Economic Review 9, 75-107.

Bekaert, G. and C. R. Harvey, 1995, Time-varying world market integration, The Journal of Finance, 50, $403-444$.

Bekaert, G. and C. R. Harvey, 2000, Foreign speculators and emerging equity markets, The Journal of Finance 55, $565-613$.

Bekaert, G. and C. R. Harvey, 2003, Emerging markets finance, Journal of Empirical Finance $10,3-55$.

Bekaert, G., Harvey, C. R, and R. L. Lumsdaine, 2002, The dynamics of emerging market equity flows, Journal of International Money and Finance 21, 295 - 350.

Bekaert, G., Harvey, C. R. Lundbald, C. and S. Siegal, 2007, Global Growth Opportunities and Market Integration, Journal of Finance 62, 1081-1137.

Bohn, H. and L.L. Tesar, 1996, U.S equity investment in foreign markets: Portfolio rebalancing or return chasing? The American Economic Review 86, 77-81.

Chan, K., Covrig, V. and L. NG, 2005, What Determines the Domestic Bias and Foreign Bias? Evidence from Mutual Fund Equity Allocations Worldwide. Journal of Finance $60,1495-1534$. 
Chinn, M. D. and H. Ito, 2008, Journal of Comparative Policy Analysis: Research and Practice 10, 309-322.

Claessens, S., Djankov, S., Joseph, F. and L. Lang, 2002, Disentangling the incentive and entrenchment effects of large shareholdings, Journal of Finance 57, 2379-2408.

Dialog, T, 1999, Corporate Governance in Russia, Moscow, May

Eleswarapu, V. R and K. Venkataraman, 2006, The Impact of Legal and Political Institutions on Equity Trading Costs: A Cross-Country Analysis, Review of Financial Studies 19, 1081-1111.

Errunza, V., 2001, Foreign portfolio equity investments, financial liberalization, and economic development, Review of International Economics 9, $703-726$.

Fidora, M., Fratzscher, M. and C. Thimann, 2007, Home bias in global bond and equity markets: The role of real exchange rate volatility. Journal of International Money \& Finance 26, 631-655.

French, K. R. and J. M., Poterba, 1991. Investor diversification and international equity markets. American Economic Review, Papers and Proceedings 81, 222-226.

Gelos, R. G. and Shang-Jin. Wei, 2005, Transparency and International Portfolio Holdings, Journal of Finance 60, 2987-3020.

Griffin, J. M., Nardari, F. and R. M. Stulz, 2004, Are Daily Cross-Border Equity Flows: Pushed or Pulled? Review of Economics und Statistics 86, 641-657.

Hunter, D. M, 2005, What Drives Time Variation in Emerging Market Segmentation? The Journal of Financial Research 28, $261-280$. 
Jensen, M.C and W.H. Meckling, 1976, Theory of firm: managerial behavior, agency cost, and ownership structure, Journal of Financial Economics 3, 305-360.

Johnson, S., Boone, P., Breach, A., and E. Freidman 2000, Corporate governance in the Asian financial crisis, Journal of Financial Economics 58, 141 - 186.

Karlsson, A. and L. Nordén, 2007. Home sweet home: Home bias and international diversification among individual investors. Journal of Banking \& Finance 31, 317-333.

La Porta, R., Lopez-de-Silanes, F., Shleifer, A. and R.W. Vishny, 1997, Legal Determinants of External Finance, Journal of Finance 52, 1131-1150.

La Porta, R., Lopez-De-Silanes, F., Shleifer, A., and R.W. Vishny, 1998, Law and finance, Journal of Political Economy 106, 1113-1155.

La Porta, R., F. Lopez-de-Silanes, A. Schleifer, R. Vishny, 1999, Corporate ownership around the world. Journal of Finance 54, 471-517.

La Porta, R., Lopez-de-Silanes, F., Shleifer, A. and R.W. Vishny, 2000, Investor protection and corporate governance, Journal of Financial Economics 58, 3-27.

Nenova, T., 1999, The value of a corporate vote and private benefits: a cross-country analysis, Working Paper Series, Harvard University, Cambridge, MA.

Reesse, W. and M. Weisbach, 2002, Protection of minority shareholder interests, crosslistings in the United States, and subsequent equity offerings, Journal of Financial Economics 66,1, 65-104.

Subramanian, A. and S. Wei, 2007, The WTO promotes trade, strongly but unevenly. Journal of International Economics 72, 151-175. 
Tesar, L. L. and I. M. Werner, 1995, Home bias and high turnover. Journal of International Money and Finance 14, $467-492$.

Warnock, F. E., 2001, Home bias and high turnover reconsidered. Journal of International Money and Finance 21, $795-805$.

Zingales, L. 1994, The Value of the Voting Right: A Study of the Milan Stock Exchange Experience, Review of Financial Studies 7, 125-14 
Table 1: Descriptive statistics: Sample averages for 2001-2006

\begin{tabular}{|c|c|c|c|c|c|}
\hline Country & $\begin{array}{c}\text { Portfolio } \\
\text { Allocation (\%) }\end{array}$ & $\underset{(0-12)}{\text { IPI }}$ & $\begin{array}{c}\text { IPII } \\
(0-16)\end{array}$ & $\begin{array}{r}\text { Composite } \\
\text { (IPI + IPII) }\end{array}$ & $\begin{array}{c}\text { Common } \\
\text { English } \\
\text { Law (IPIII) }\end{array}$ \\
\hline Finland & 2.10 & 12.00 & 16.00 & 28.00 & 0 \\
\hline Sweden & 2.09 & 12.00 & 15.25 & 27.25 & 0 \\
\hline New Zealand & 0.15 & 11.83 & 15.33 & 27.17 & 1 \\
\hline Denmark & 0.56 & 11.61 & 15.50 & 27.11 & 0 \\
\hline Austria & 0.45 & 12.00 & 15.00 & 27.00 & 0 \\
\hline Canada & 1.71 & 12.00 & 14.68 & 26.68 & 1 \\
\hline Norway & 0.57 & 11.58 & 15.00 & 26.58 & 0 \\
\hline UK & 15.73 & 12.00 & 14.17 & 26.17 & 1 \\
\hline Australia & 1.46 & 11.33 & 14.50 & 25.83 & 1 \\
\hline Germany & 8.82 & 12.00 & 13.50 & 25.50 & 0 \\
\hline Switzerland & 5.33 & 11.75 & 13.50 & 25.25 & 0 \\
\hline USA & 37.76 & 11.67 & 13.58 & 25.25 & 1 \\
\hline Belgium & 1.08 & 11.61 & 12.92 & 24.54 & 0 \\
\hline Japan & 7.94 & 11.67 & 12.50 & 24.17 & 0 \\
\hline Portugal & 0.27 & 11.91 & 11.67 & 23.58 & 0 \\
\hline France & 10.81 & 12.00 & 11.00 & 23.00 & 0 \\
\hline Chile & 0.04 & 11.07 & 11.67 & 22.74 & 0 \\
\hline Hungary & 0.20 & 11.74 & 10.59 & 22.33 & 0 \\
\hline Czech & 0.09 & 11.63 & 10.59 & 22.22 & 0 \\
\hline Taiwan & 0.58 & 11.53 & 10.41 & 21.94 & 0 \\
\hline Italy & 3.43 & 11.92 & 9.00 & 20.92 & 0 \\
\hline Poland & 0.17 & 11.07 & 9.34 & 20.41 & 0 \\
\hline Greece & 0.28 & 10.67 & 9.08 & 19.75 & 0 \\
\hline Mexico & 0.42 & 11.17 & 7.49 & 18.66 & 0 \\
\hline Malaysia & 0.15 & 8.75 & 8.92 & 17.67 & 1 \\
\hline India & 0.31 & 8.57 & 8.99 & 17.56 & 1 \\
\hline Turkey & 0.19 & 7.84 & 8.66 & 16.50 & 0 \\
\hline Philippines & 0.04 & 9.42 & 6.99 & 16.42 & 0 \\
\hline Korea & 1.07 & 9.65 & 6.00 & 15.65 & 0 \\
\hline Thailand & 0.18 & 8.59 & 7.03 & 15.62 & 1 \\
\hline Peru & 0.02 & 8.00 & 7.33 & 15.33 & 0 \\
\hline China & 0.41 & 7.29 & 7.99 & 15.28 & 0 \\
\hline Russia & 0.58 & 8.83 & 6.40 & 15.23 & 0 \\
\hline Brazil & 0.54 & 7.75 & 6.67 & 14.42 & 0 \\
\hline Argentina & 0.05 & 6.05 & 7.98 & 14.03 & 0 \\
\hline Indonesia & 1.01 & 6.51 & 5.75 & 12.26 & 0 \\
\hline
\end{tabular}




\section{Table 2: Base Regression}

The dependent variable is the log value of country wise bilateral foreign portfolio allocation from country $i$ in country $j$ at time $\mathrm{t}\left(w_{i, j, t}\right)$. The key independent variables of interest are investor profile (IPI), quality of institution (IPII) and English common law dummy (IPII). The only controls are bilateral home bias (Hbias) and interactive term (Hbias_IP).

$$
w_{i j t}=\alpha+\beta_{1} . \text { Hbias }_{i j t}+\beta_{2} . \text { Hbias_IP }_{i j t}+\beta_{3} . \text { Investor protection } \text { prt }_{1}+\epsilon_{i j t}
$$

Regressions with IPI and IPII as independent variables are estimated using fixed effect model and with IPIII (Common English law dummy) using random effect model. Test-statistics are given in parentheses (based on robust standard error allowing for clustering within the cross sectional units). All the coefficients are interpreted as elasticity. Significant coefficients are indicated with $*$ denoting significance at $10 \%, * *$ at $5 \%$ and $* * *$ at $1 \%$ significance level.

\begin{tabular}{lccc}
\hline & IPI & IPII & IPII \\
\hline Hbias & $-0.836^{* * *}$ & $-0.826^{* * *}$ & $-0.817^{* * *}$ \\
& $(-19.72)$ & $(-19.97)$ & $(-58.58)$ \\
Investor protection & $14.81^{* * *}$ & $17.63^{* * *}$ & $1.208^{* * * *}$ \\
& $(13.11)$ & $(12.26)$ & $(6.19)$ \\
Hbias_Investor protection & $-1.217^{* * * *}$ & $-1.090^{* * *}$ & $-0.143^{*}$ \\
& $(-2.90)$ & $(-2.69)$ & $(-1.85)$ \\
& & & 0.35 \\
\hline Overall $\mathrm{R}^{2}$ & 0.38 & 0.43 & 3288 \\
\hline Number of observations & 3288 & 3288 & \\
\hline
\end{tabular}




\section{Table 3: Regression with investor protection and all controls}

The dependent variable $\left(w_{i, j, t}\right)$. is the log value of country wise bilateral foreign portfolio allocation from country $i$ in country $j$ at time $t$. The key independent variables of interest are investor protection measures which includes investor profile (IPI), quality of institution (IPII) and English common law dummy (IPII). The controls are bilateral home bias, (Hbias), Hbias_IP, stock market development/size, liquidity/transaction cost, equity market volatility, bilateral trade, common (pair countries) language dummy (pair countries), log distance between capital cities of the pair countries, three year moving average historical return, country financial risk (components are: foreign debt as \% of GDP, exchange rate stability, foreign debt as $\%$ of total export and services, current account as \% of exports and services and international liquidity), country economic risk (components are: GDP per head, Real GDP growth, inflation rate, budget balance as \% of GDP, current account as \% of GDP) and capital control.

$$
w_{i j t}=\alpha+\beta_{1} \text {. Investor protection } n_{j t}+\beta_{2} \text {. Controls }+\epsilon_{i j t}
$$

Regressions with IPI and IPII as independent variables are estimated using fixed effect model and with IPIII (Common English law dummy) using random effect model. Test-statistics are given in parentheses (based on robust standard error allowing for clustering within the cross sectional units). All the coefficients are interpreted as elasticity. Significant coefficients are indicated with * denoting significance at $10 \%, * *$ at $5 \%$ and $* * *$ at $1 \%$ significance level.

\begin{tabular}{lccc}
\hline & IPI & IPII & IPIII \\
\hline Hbias & $-0.783^{* * *}$ & $-0.846^{* * *}$ & $-0.800^{* * *}$ \\
Investor protection & $(-17.48)$ & $(-28.71)$ & $(-75.17)$ \\
& $4.241^{* * *}$ & $7.529^{* * *}$ & $0.899^{* * *}$ \\
Hbias_Investor protection & $(4.20)$ & $(7.53)$ & $(7.07)$ \\
& $-1.497^{* * *}$ & $-0.744^{* * *}$ & $-0.0464^{* *}$ \\
Stock market development/size & $(-3.47)$ & $(-2.72)$ & $(-2.23)$ \\
& $0.633^{* * *}$ & $0.627^{* * *}$ & $0.647 * * *$ \\
Transaction cost & $(22.51)$ & $(24.12)$ & $(22.12)$ \\
& $10.01^{* * *}$ & $10.39^{* * *}$ & $15.01^{* * *}$ \\
Equity market volatility & $(5.47)$ & $(6.07)$ & $(7.72)$ \\
& $-0.133^{* * *}$ & $-0.125^{* * *}$ & $-0.128^{* * *}$ \\
Common language & $(-6.58)$ & $(-5.99)$ & $(-6.36)$ \\
& $\mathrm{NA}$ & $\mathrm{NA}$ & $0.339^{* * *}$ \\
Bilateral trade & & & $(3.03)$ \\
Distance & $0.784^{* * *}$ & $0.650^{* * *}$ & $1.457^{* * *}$ \\
& $(4.73)$ & $(4.06)$ & $(8.72)$ \\
Historical return & $\mathrm{NA}$ & $\mathrm{NA}$ & $-0.213^{* * * *}$ \\
& & & $(-4.80)$ \\
Country financial risk & 0.0154 & 0.0294 & $-0.0655^{* *}$ \\
Country economic risk & $(0.51)$ & $(1.05)$ & $(-2.24)$ \\
Capital market openness & $1.326^{* * *}$ & $1.544^{* * *}$ & $1.175^{* * *}$ \\
& $(8.76)$ & $(10.35)$ & $(7.62)$ \\
Overall $\mathrm{R}^{2}$ & $0.664^{* * *}$ & $0.490^{* * *}$ & $0.704^{* * *}$ \\
Number of observations & $(2.91)$ & $(2.19)$ & $(2.65)$ \\
& 0.0558 & -1.932 & $4.211^{* *}$ \\
& $(0.03)$ & $(-0.88)$ & $(2.11)$ \\
\hline
\end{tabular}




\section{Table 4: Regression with lagged investor protection and all controls}

The dependent variable $\left(w_{i, j, t}\right)$. is the log value of country wise bilateral foreign portfolio allocation from country $i$ in country $j$ at time $t$. The key independent variables of interest are one year lagged value of investor protection measures which includes investor profile (IPI) and quality of institution (IPII). The controls are bilateral home bias (Hbias), Hbias_IP, stock market development/size, liquidity/transaction cost, equity market volatility, bilateral trade, common (pair countries) language dummy (pair countries), log distance between capital cities of the pair countries, three year moving average historical return, country financial risk (components are: foreign debt as \% of GDP, exchange rate stability, foreign debt as \% of total export and services, current account as \% of exports and services and international liquidity), country economic risk (components are: GDP per head, Real GDP growth, inflation rate, budget balance as \% of GDP, current account as \% of GDP) and capital control.

$$
w_{i j t}=\alpha+\beta_{1} . \text { Investor protection }_{j t-1}+\beta_{2} \text {. Controls }+\epsilon_{i j t}
$$

Regressions with IPI and IPII as independent variables are estimated using fixed effect model. Test-statistics are given in parentheses (based on robust standard error allowing for clustering within the cross sectional units). All the coefficients are interpreted as elasticity. Significant coefficients are indicated with * denoting significance at $10 \%, * *$ at $5 \%$ and $* * *$ at $1 \%$ significance level.

\begin{tabular}{lcc}
\hline & IPI & IPII \\
\hline Hbias & $-0.840^{* * *}$ & $-0.926^{* * *}$ \\
& $(-19.83)$ & $(-31.52)$ \\
Lagged Investor protection & $3.747^{* * *}$ & 0.111 \\
& $(5.09)$ & $(0.15)$ \\
Hbias_Investor protection & $-1.185^{* * *}$ & -0.207 \\
& $(-2.93)$ & $(-0.76)$ \\
Stock market development/size & $0.473^{* * *}$ & $0.489^{* * *}$ \\
& $(17.67)$ & $(19.61)$ \\
Transaction cost & $11.46^{* * *}$ & $10.38^{* * *}$ \\
& $(5.57)$ & $(5.26)$ \\
Equity market volatility & $-0.102^{* * *}$ & $-0.113^{* * *}$ \\
& $(-5.82)$ & $(-6.09)$ \\
Common language & $\mathrm{NA}$ & $\mathrm{NA}$ \\
Bilateral trade & & $1.025^{* * * *}$ \\
Distance & $0.951^{* * *}$ & $(6.17)$ \\
Historical return & $(6.07)$ & $\mathrm{NA}$ \\
Country financial risk & $\mathrm{NA}$ & \\
& & 0.0320 \\
Country economic risk & $0.0432^{*}$ & $(1.34)$ \\
Capital market openness & $(1.73)$ & $1.011^{* * *}$ \\
& $0.817^{* * *}$ & $(5.87)$ \\
\hline Overall $\mathrm{R}^{2}$ & $(4.66)$ & $1.107 * * *$ \\
Number of observations & $1.367^{* * *}$ & $(4.47)$ \\
& $(5.33)$ & 3.330 \\
& 4.261 & $(1.20)$ \\
\hline & $(1.55)$ & 0.558 \\
& 0.568 & 2616 \\
\hline
\end{tabular}


Table 5: Vector autoregression

Vector auto regressions using one year lagged value of $w_{i j t}$ and Investor protection. The controls are same as specified in table 4 . The top tow represents dependent variables.

$$
\begin{gathered}
w_{i j t}=\alpha+\beta_{1} \cdot w_{i j t-1}+\beta_{2} \cdot \text { Investor protection }_{j t-1}+\beta_{3} \cdot \text { Controls }+\epsilon_{i j t} \\
\text { Investor protection }_{j t}=\alpha+\beta_{1} \text {. Investor protection } \text { Int-1 }_{j+1}+\beta_{2} \cdot w_{i j t-1}+\beta_{3} . \text { Controls }+\epsilon_{i j t}
\end{gathered}
$$

Regressions are estimated using simple OLS. Test-statistics are given in parentheses (based on robust standard error). All the coefficients are interpreted as elasticity. Significant coefficients are indicated with $*$ denoting

\begin{tabular}{|c|c|c|c|c|}
\hline & IEPA & IPI & IEPA & IPII \\
\hline Lagged IEPA & $\begin{array}{c}0.778 * * * \\
(89.33)\end{array}$ & $\begin{array}{l}0.0161 \\
(1.02)\end{array}$ & $\begin{array}{c}0.782 * * * \\
(89.75)\end{array}$ & $\begin{array}{c}0.0263 \\
(1.41)\end{array}$ \\
\hline Lagged IPI & $\begin{array}{c}1.309 * * * \\
(3.88)\end{array}$ & $\begin{array}{c}0.837 * * * \\
(77.00)\end{array}$ & & \\
\hline Lagged IPII & & & $\begin{array}{l}0.557 \\
(1.02)\end{array}$ & $\begin{array}{c}0.909 * * * \\
(73.37)\end{array}$ \\
\hline Hbias & $\begin{array}{c}-0.371 * * * \\
(-9.90)\end{array}$ & $\begin{array}{c}-0.456 * * * \\
(-13.61)\end{array}$ & $\begin{array}{c}-0.325 * * * \\
(-11.72)\end{array}$ & $\begin{array}{c}-0.213 * * * \\
(-6.71)\end{array}$ \\
\hline Hbias_Investor protection & $\begin{array}{c}-1.054 * * * \\
(-2.83)\end{array}$ & $\begin{array}{c}1.764 * * * \\
(14.21)\end{array}$ & $\begin{array}{c}-0.682 * * \\
(-2.58)\end{array}$ & $\begin{array}{c}1.616 * * * \\
(8.58)\end{array}$ \\
\hline Stock market development/size & $\begin{array}{c}0.221 * * * \\
(10.40)\end{array}$ & $\begin{array}{c}0.108 * * * \\
(5.57)\end{array}$ & $\begin{array}{c}0.216^{* * * *} \\
(9.98)\end{array}$ & $\begin{array}{c}0.127 * * * \\
(5.09)\end{array}$ \\
\hline Transaction cost & $\begin{array}{c}2.444 * * * \\
(9.95)\end{array}$ & $\begin{array}{c}1.872 * * * \\
(8.29)\end{array}$ & $\begin{array}{c}2.483 * * * \\
(9.90)\end{array}$ & $\begin{array}{c}3.120 * * \\
(2.07)\end{array}$ \\
\hline Equity market volatility & $\begin{array}{c}-0.0345^{* * *} * \\
(-3.83)\end{array}$ & $\begin{array}{c}0.0143 \\
(0.37)\end{array}$ & $\begin{array}{c}-0.0677 * * * \\
(-4.64)\end{array}$ & $\begin{array}{c}-0.286 * * * \\
(-5.97)\end{array}$ \\
\hline Common language & $\begin{array}{c}0.356 * * * \\
(3.13)\end{array}$ & $\begin{array}{c}0.0272 \\
(1.06)\end{array}$ & $\begin{array}{c}0.0195 * * * \\
(4.07)\end{array}$ & $\begin{array}{c}0.0414 \\
(1.27)\end{array}$ \\
\hline Bilateral trade & $\begin{array}{c}0.406 * * * \\
(6.93)\end{array}$ & $\begin{array}{l}-0.0946 \\
(-0.02)\end{array}$ & $\begin{array}{c}0.413 * * * \\
(7.02)\end{array}$ & $\begin{array}{c}0.0278 \\
(0.41)\end{array}$ \\
\hline Distance & $\begin{array}{c}-0.0579 * * * \\
(-4.92)\end{array}$ & $\begin{array}{l}-0.0325 \\
(-1.01)\end{array}$ & $\begin{array}{c}-0.0466 * * * \\
(-3.98)\end{array}$ & $\begin{array}{c}-0.0495 \\
(-0.64)\end{array}$ \\
\hline Historical return & $\begin{array}{l}-0.0841 \\
(-1.34)\end{array}$ & $\begin{array}{c}0.228 * * * \\
(5.73)\end{array}$ & $\begin{array}{c}-0.0875 \\
(-0.97)\end{array}$ & $\begin{array}{c}0.171 * * * \\
(3.32)\end{array}$ \\
\hline Country financial risk & $\begin{array}{c}1.752 * * * \\
(7.54)\end{array}$ & $\begin{array}{c}0.735^{* * *} \\
(3.45)\end{array}$ & $\begin{array}{c}1.912 * * * \\
(8.13)\end{array}$ & $\begin{array}{c}0.498^{*} \\
(1.83)\end{array}$ \\
\hline Country economic risk & $\begin{array}{c}1.385^{* * * *} \\
(3.68)\end{array}$ & $\begin{array}{c}2.431 * * * \\
(7.04)\end{array}$ & $\begin{array}{c}1.723 * * * \\
(4.26)\end{array}$ & $\begin{array}{c}3.329 * * * \\
(7.11)\end{array}$ \\
\hline Capital market openness & $\begin{array}{l}1.006 \\
(3.83)\end{array}$ & $\begin{array}{c}7.021 * * * \\
(6.32)\end{array}$ & $\begin{array}{c}3.338 * * * \\
(3.03)\end{array}$ & $\begin{array}{l}-0.198 \\
(-0.16)\end{array}$ \\
\hline Adjusted $\mathrm{R}^{2}$ & 0.852 & 0.843 & 0.851 & 0.870 \\
\hline Number of observations & 2616 & 2618 & 2616 & 2618 \\
\hline
\end{tabular}
significance at $10 \%, * *$ at $5 \%$ and $* * *$ at $1 \%$ significance level. 
Table 6: Regression with investor protection, all controls but sample excludes USA, UK and Japan as investor countries

The dependent variable $\left(w_{i, j, t}\right)$. is the log value of country wise bilateral foreign portfolio allocation from country $i$ in country $j$ at time $t$. The key independent variables of interest are investor protection measures which includes investor profile (IPI), quality of institution (IPII) and English common law dummy (IPII). The controls are bilateral home bias (Hbias), Hbias_IP, stock market development/size, liquidity/transaction cost, equity market volatility, bilateral trade, common (pair countries) language dummy (pair countries), log distance between capital cities of the pair countries, three year moving average historical return, country financial risk (components are: foreign debt as \% of GDP, exchange rate stability, foreign debt as \% of total export and services, current account as \% of exports and services and international liquidity), country economic risk (components are: GDP per head, Real GDP growth, inflation rate, budget balance as \% of GDP, current account as \% of GDP) and capital control.

$$
w_{i j t}=\alpha+\beta_{1} \text {. Investor protection } n_{j t}+\beta_{2} \text {. Controls }+\epsilon_{i j t}
$$

Regressions with IPI and IPII as independent variables are estimated using fixed effect model and with IPIII (Common English law dummy) using random effect model. Test-statistics are given in parentheses (based on robust standard error allowing for clustering within the cross sectional units). All the coefficients are interpreted as elasticity. Significant coefficients are indicated with * denoting significance at $10 \%, * *$ at $5 \%$ and $* * *$ at $1 \%$ significance level.

\begin{tabular}{lccc}
\hline & IPI & IPI & IPII \\
\hline Hbias & $-0.786^{* * *}$ & $-0.847^{* * *}$ & $-0.903^{* * *}$ \\
& $(-16.10)$ & $(-26.91)$ & $(-69.04)$ \\
Investor protection & $4.549^{* * *}$ & $7.572^{* * *}$ & $0.964^{* * *}$ \\
& $(4.18)$ & $(6.82)$ & $(6.93)$ \\
Hbias_Investor protection & $-1.505^{* * *}$ & $-0.766^{* * *}$ & $-0.0525^{* *}$ \\
& $(-3.18)$ & $(-2.64)$ & $(-2.33)$ \\
Stock market development/size & $0.633^{* * *}$ & $0.625^{* * *}$ & $0.643^{* * *}$ \\
& $(20.35)$ & $(21.78)$ & $(19.69)$ \\
Transaction cost & $10.08^{* * *}$ & $10.29 * * *$ & $15.24^{* * *}$ \\
& $(4.98)$ & $(5.44)$ & $(6.99)$ \\
Equity market volatility & $-0.134^{* * *}$ & $-0.127^{* * *}$ & $-0.126^{* * *}$ \\
& $(-5.94)$ & $(-5.52)$ & $(-5.60)$ \\
Common language & $\mathrm{NA}$ & $\mathrm{NA}$ & $0.453^{* * *}$ \\
& & & $(3.75)$ \\
Bilateral trade & $0.656^{* * *}$ & $0.546^{* * *}$ & $1.397^{* * *}$ \\
& $(3.85)$ & $(3.30)$ & $(7.56)$ \\
Distance & $\mathrm{NA}$ & $\mathrm{NA}$ & $-0.197^{* * *}$ \\
& & & $(-3.92)$ \\
Historical return & 0.0236 & 0.0380 & $-0.0659^{* * *}$ \\
Country financial risk & $(0.70)$ & $(1.22)$ & $(-1.99)$ \\
& $1.329^{* * *}$ & $1.543^{* * *}$ & $1.153^{* * *}$ \\
Country economic risk & $(7.79)$ & $(9.18)$ & $(6.56)$ \\
Capital market openness & $0.723^{* * *}$ & $0.530^{* *}$ & $0.730^{* *}$ \\
& $(2.89)$ & $(2.15)$ & $(2.45)$ \\
Overall $\mathrm{R}^{2}$ & 0.276 & -1.622 & $4.544^{* *}$ \\
Number of observations & $(0.12)$ & $(-0.66)$ & 0.668 \\
\hline
\end{tabular}

